\title{
Plastic Waste Pollution Worsen by the COVID-19 Pandemic: Substitutional Technologies Transforming Plastic Waste to Value Added Products
}

\author{
Djamel Ghernaout ${ }^{1,2 *}$, Noureddine Elboughdiri1,3 \\ ${ }^{1}$ Chemical Engineering Department, College of Engineering, University of Ha'il, Ha'il, Saudi Arabia \\ ${ }^{2}$ Chemical Engineering Department, Faculty of Engineering, University of Blida, Blida, Algeria \\ ${ }^{3}$ Chemical Engineering Process Department, National School of Engineering, University of Gabes, Gabes, Tunisia \\ Email: ^djamel_andalus@hotmail.com
}

How to cite this paper: Ghernaout, D. and Elboughdiri, N. (2021) Plastic Waste Pollution Worsen by the COVID-19 Pandemic: Substitutional Technologies Transforming Plastic Waste to Value Added Products. Open Access Library Journal, 8: e7622. https://doi.org/10.4236/oalib.1107622

Received: June 9, 2021

Accepted: June 28, 2021

Published: July 1, 2021

Copyright $\odot 2021$ by author(s) and Open Access Library Inc.

This work is licensed under the Creative Commons Attribution International License (CC BY 4.0).

http://creativecommons.org/licenses/by/4.0/

\begin{abstract}
Throughout the world, Coronavirus Disease 2019 (COVID-19) pandemic possesses an enormous effect on the plastic waste management because of the unexpected flow of medical waste that has been conducted to a universal waste management calamity. Inappropriate handling of plastic waste could conduct to numerous unwanted effects on nature, animals, and human beings. Nevertheless, following appropriate waste management and the valid techniques, considering in a dissimilar manner of the existing catastrophe would be a chance. Approximately $40 \%$ of the plastic waste ended up in landfill, $25 \%$ incinerated, $16 \%$ recycled and the remaining $19 \%$ are discharged into nature. The augmentation of plastic wastes and demand of plastic markets work as a good economic measure for investors and government initiatives to invest in techniques that transform plastic waste into value-added products like fuel and construction materials. This will close the loop of the life cycle of plastic waste via attaining a sustainable circular economy. This short discussion furnishes insight of the state of plastic waste before and during the COVID-19 pandemic. The treatment route of plastic waste like sterilization technology, incineration, and substitutional techniques obtainable in transforming plastic waste into value-added products are briefly assessed. More performant, flexible and advanced technologies of dealing with the plastic wastes under dangerous catastrophes ought to be continuously suggested. Every action followed will participate to the importance of such problem since this is a key aim of the community to safe a cleaner and greener nature.
\end{abstract}




\section{Subject Areas}

Chemical Engineering \& Technology

\section{Keywords}

Coronavirus Disease 2019 (COVID-19), Plastic Waste, Medical Waste, Waste Management, Value-Added Product

\section{Introduction}

COVID-19 possesses a coronavirus-specific nucleic acid sequence that is distinct from already recognized human coronaviruses provoked by severe acute respiratory syndrome coronavirus 2 (SARS-CoV-2) [1] [2] [3] and is identical to those observed in bats [4]. As COVID-19 is an airborne disease, the virus could be diffused readily via air droplets exhale out from a contaminated human's mouth or nose [5] [6] [7]. Most of the signs are moderate; however, in intense cases, the sick persons will suffer from signs like pneumonia, pulmonary oedema and organ failure that could be fatal [1] [8] [9]. On 30th January 2020, the COVID-19 pandemic was announced as Public Health Emergency of International Concern [10] following a large evaluation of the epidemic. Because of the gravity of the trouble, the disease was declared as a pandemic on 11th March 2020 [1] [10].

Throughout the world, numerous protective programs (e.g., washing hands frequently, social and physical distancing) have been suggested to diminish the probabilities of diffusing of COVID-19. As seen above, COVID-19 virus propagates via airborne in which liquid droplets are sprayed out from the mouth and nose when the person coughs or sneezes. Moreover, social gatherings neither large- and small-scale were banned during the lockdown since when people come in crowded places, the ventilation of the enclosed space becomes deficient. Then, it is obligatory to wear face masks to decrease the risks of the airborne virus entering the human body by nose or mouth. Further, actions like touching our eyes, nose and mouth must be averted in public areas as a lot of pathogens can be existing on the surface of the hands after contacting with different objects [1].

Misfortunes do not come singly as the globe not only confronting the COVID-19 pandemic but as well struggling with the augmentation of wastes mostly from plastics to both the society and healthcare sectors [1]. Even if the present protective actions demanded by the governments was to block more wave of COVID-19 spreading, the appearance of plastic waste is being quickly formed unintentionally like the plastic bottles of sanitizer, facial mask, and surgical gloves because of the elevated production and purchasing volume to satisfy the need of the society [1]. Plastics have outstanding strength, durability and versatility, particularly in healthcare sector with major application in single-used plastic medical tools, 
equipment, and packaging [11]. The Personal Protective Equipment (PPE) could be formed of different kinds of plastics like Low-Density Polyethylene (LDPE), High Density Polyethylene (HDPE), Polyethylene Terephthalate (PET), Polyvinyl Chloride (PVC), Polypropylene (PP), Polycarbonate and Polystyrene (PS) [1]. Employing PPE can be life-savior throughout such pandemic; however, the collection, mismanagement and littering of such plastic wastes could lead to an abrupt collapse of waste management chains that will provoke grave environmental contamination in both terrestrial and marine ecosystems. In addition, the deluge of medical wastes augmented considerably throughout the COVID-19 disease. For example, Wuhan (China), the famous city from which COVID-19 broke out, produced 200 tons of clinical trash on the exact day, 24th of February 2020 [1]. The quantity of trash is four times the quantity the city's only dedicated facility can incinerate per day [12]. For 7.8 billion population across the globe, the monthly consumption is evaluated at 129 billion for facial masks and 65 billion for surgical gloves [13]. The demand and supply of plastic-based PPE against the actual catastrophe have been anticipated to augment around $40 \%$ per month in the supply chain of different safety products worldwide [1].

As a consequence, Khoo et al. [1] discussed the present state-of-the-art of plastic wastes prior and throughout the COVID-19 outbreak. They estimated the technologies implied in the treatment pathway of plastic waste management [1]. The present review gives a brief insight of the techniques obtainable in fate of converting plastic waste into value-added products. Since global plastic waste persists to augment, scientists have to use such waste resources and transform them into value-added products via merging the actual obtainable techniques, transforming the actual crisis into an opportunity for the future industries.

\section{Substitutional Technologies Transforming Plastic Waste to Value Added Products}

Despite the fact that incineration is a frequent application for dealing with plastic waste, it possesses numerous unfavorable effects on the nature (Figure 1) [1]. Some investigations [14] revealed that waste incineration possesses approximately 50 effects on the nature. The four highest ecological effects remain marine aquatic ecotoxicity, marine sediment ecotoxicity, acidification and ionizing radiation [14]. Consequently, substitutional techniques with less unwanted influences on the nature and human health appeal more studies and amelioration. Such situation is worsen by the effect of medical waste on plastic waste because of the actual COVID-19 pandemic [1]. Such circumstance could present an occasion to exploit in techniques for transforming plastic waste into value added products. The augmenting production of plastic wastes and the augmenting demand of plastic markets work as a good economic index. In addition, building novel company can even form more job chances. Because of the COVID-19 pandemic, as of 6th April 2020, 20 million jobs had been lost only in the United States with an elevation in the unemployment rate of $12.2 \%$ [1]. As a result, the 


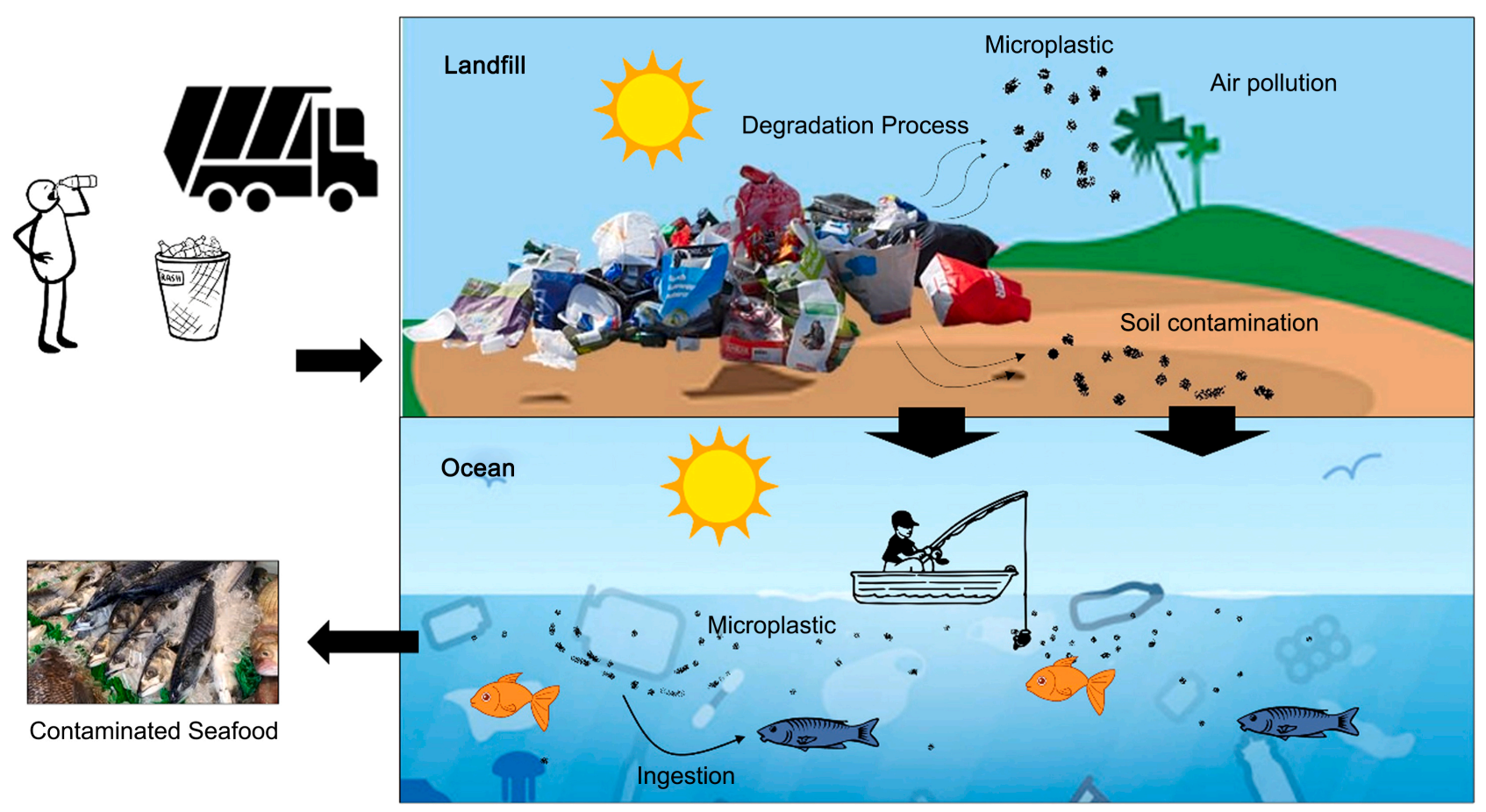

Figure 1. Unwanted influence of plastic waste on the nature [1].

presently obtainable substitutional techniques for transforming plastic waste into value added product could assist the actual COVID-19 pandemic crisis converting it into occasions and diminish the undesirable influence of plastic waste on the nature and human health.

Transforming plastic waste to fuel has been investigated during several years and it is not a fresh path [1]. Because of the augmentation of plastic waste generally, there has been a switch in study attention where there has been numerous investigations on enhancing the processes applied in transforming plastic waste to fuel. Several techniques may be cited like chemo-lysis, pyrolysis, fluid catalytic cracking, hydrogen technologies, catalytic pressure-less depolymerization process (known as KDV process, KDV is a German acronym for Katalytische Drucklose Verölung or the catalytic pressure-less depolymerization process, it was suggested by the German company Alphakat GmbH, it affirms the catalytic conversion of biomass and plastic waste towards liquid fuels at nearly atmospheric pressure) and gasification as listed in Table 1 [15].

One of the popular techniques implied in the transformation of plastic waste into fuel is known as pyrolysis [1]. Pyrolysis could be further divided into thermal pyrolysis, catalytic pyrolysis and microwave-assisted pyrolysis [16] [17] [18] [19]. As a fresh development, microwave-assisted pyrolysis had attracted much interest from scientists thanks to its numerous benefits like faster heating rate and cost effectiveness juxtaposed to different kinds of pyrolysis [20]. Throughout pyrolysis, plastic waste is intensely heated $\left(\sim 500^{\circ} \mathrm{C}\right)$ in a short time and oxygen deficient medium; in such circumstances, long chain, macromolecular structures of polymers decompose into smaller polymer molecules or oligomers 
Table 1. Large assessment of the different techniques employed in transforming plastic waste to fuels [1].

\begin{tabular}{|c|c|c|}
\hline Technologies & Function & Conditions \\
\hline Chemo-lysis & $\begin{array}{l}\text { Depolymerizes plastic into its } \\
\text { monomer through various } \\
\text { depolymerization routes: } \\
\text { methanolysis, glycolysis, hydrolysis, } \\
\text { ammonolysis and hydrogenation. }\end{array}$ & $\begin{array}{c}\text { Methanolysis: } \\
\text { Temperature: } 180^{\circ} \mathrm{C}-280^{\circ} \mathrm{C} \text {. } \\
\text { Pressure: } 20-40 \text { atm. } \\
\text { Hydrolysis: the reaction of plastic } \\
\text { with water under neutral, acidic } \\
\text { or basic conditions at high } \\
\text { temperature and pressure. } \\
\text { Glycolysis: } \\
\text { Temperature: } 180^{\circ} \mathrm{C}-250^{\circ} \mathrm{C} \text { with } \\
\text { excess of glycol. }\end{array}$ \\
\hline Pyrolysis & $\begin{array}{l}\text { Breaks down macrostructure of the } \\
\text { polymer to form smaller molecules } \\
\text { by depolymerization or random } \\
\text { fragmentation. The pyrolysis products } \\
\text { of plastic waste can be in the forms } \\
\text { of gas, liquid and solid residue. }\end{array}$ & $\begin{array}{l}\text { Temperature: } 500^{\circ} \mathrm{C} . \\
\text { Pressure: } 1 \text { - } 2 \mathrm{~atm} .\end{array}$ \\
\hline $\begin{array}{l}\text { Fluid catalytic } \\
\text { cracking }\end{array}$ & $\begin{array}{l}\text { Converts plastic waste into fuel, } \\
\text { commodity chemicals and fine } \\
\text { chemicals through thermal and } \\
\text { catalytic decomposition process. }\end{array}$ & Temperature: $300^{\circ} \mathrm{C}-350^{\circ} \mathrm{C}$. \\
\hline $\begin{array}{l}\text { Hydrogen } \\
\text { technologies }\end{array}$ & $\begin{array}{l}\text { Convert plastic waste into liquid fuel } \\
\text { through hydrocracking reactions. }\end{array}$ & $\begin{array}{l}\text { Temperature: } 375^{\circ} \mathrm{C}-400^{\circ} \mathrm{C} \text {. } \\
\text { Pressure: } 70 \mathrm{~atm} . \\
\text { With the addition of hydrogen gas. }\end{array}$ \\
\hline KDV process & $\begin{array}{c}\text { Catalytic depolymerization: conversion } \\
\text { of biomass and plastic waste into } \\
\text { liquid fuels such as diesel oil. }\end{array}$ & $\begin{array}{l}\text { Temperature: } 250^{\circ} \mathrm{C}-320^{\circ} \mathrm{C} \text {. } \\
\text { Pressure: Atmospheric pressure. }\end{array}$ \\
\hline Gasification & $\begin{array}{l}\text { Converts plastic waste to a gaseous } \\
\text { mixture containing } \mathrm{CO}_{2}, \mathrm{CO}, \mathrm{H}_{2}, \mathrm{CH}_{4} \\
\text { and other light hydrocarbons via } \\
\text { partial oxidation. The gaseous } \\
\text { mixture is known as syngas. }\end{array}$ & $\begin{array}{c}\text { Temperature: } 1200^{\circ} \mathrm{C}-1500^{\circ} \mathrm{C} . \\
\text { Pressure: } 50-100 \mathrm{~atm} . \\
\text { With oxygen and steam. }\end{array}$ \\
\hline
\end{tabular}

and monomeric units [1]. In this technique, the fuels generated are in the form of liquid, oil and gas with char as the by-product. Such products could be employed in the field of petroleum chemical industries, refineries, boiler for energy or power application; whilst, char generated may be utilized in the domain of wastewater treatment [21] [22] [23]. Researchers noted that the percentage of liquid fuel formed from pyrolysis of various kinds of plastics like PS, PP, LDPE, HDPE and mixed plastic are $81 \%, 80 \%, 73 \%, 70 \%$ and $46 \%$ of liquid fuel, respectively [21] [24]. It must be mentioned here that mixed plastic generates the lowest quantity of liquid fuel; thus, the sorting stage of plastic waste is so crucial [1]. Plastic waste has to be separated into its respective kind of plastic to form the highest quantity of liquid fuels when undergoes pyrolysis. Moreover, the drawback of liquid fuels that renders them not appropriate for the transportation fuel is related to the occurrence of high aromatic chemicals. Consequently, the up- 
grading of fuel with various post-treatment processes (e.g., distillation [25], refining or blending with traditional diesel) is requested for the application of transportation fuel [21]. However, this has conducted to the suggestion of microwave-assisted pyrolysis. Mahari et al. [22] noticed that the liquid oil formed via microwave-assisted co-pyrolysis (employed frying oil and plastic waste) depicted interesting green features including low oxygen content, free of nitrogen and sulfur and higher energy content $(42-46 \mathrm{MJ} / \mathrm{kg})$. In fact, more investigations should be dedicated to the domain of microwave-assisted co-pyrolysis on the suitability of liquid oil for the application of transportation without upgrading the fuel [1].

Apart from transforming plastic waste to fuel, researchers mentioned lately that employing plastic waste in the field of construction materials such as road, cements and concrete is promising. Indeed, blending demolition waste and polyethylene plastic granules with up to $5 \%$ content is found convenient for road construction material [26]. Moreover, researchers as Jassim [27] explored the chance of generating plastic cements from polyethylene waste and Portland cement with ratio proportion of 3:2, respectively. Other scientists [28] evaluated the mechanical characteristics of the integration of metallized plastic waste and geopolymer concrete. In addition, some studies depicted that substituting $10 \%$ sand by volume with recycled plastic has the capacity to save 820 million tons of sand every year [29]. Further, this could even lower the price of house construction that let low- or mid-income family to afford a house. On the other hand, the roads, house, concrete or cement are open to sunlight the whole day. This is why it remains fundamental to determine whether recycled plastic blended in the concrete will undergo thermal degradation that could form microplastic that may be dangerous to human health. Family members living in the house constructed of recycled-plastic based concrete could be open to toxic microplastic in the long term. Different value-added products like synthesis of graphene nanosheets [30], carbon nanomaterials [31], and synthesis of metal organic frameworks [32] have as well been mentioned in several investigations. Valorizing plastic waste demands more studies and amelioration in the performance and practicability of obtainable techniques. By 2040, around $80 \%$ of the plastic pollution trouble could be solved via employing present grasp and processes and at a lower price for waste management [1]. Figure 2 illustrates a global estimation of the diverse way in transforming plastic waste into value-added products [1].

\section{Future Trends and Dares}

Throughout the globe, the traditional processes employed to deal with the plastic wastes are mechanical recycling, incineration and landfilling [1]. Mechanical recycling procedure occupied $16 \%$, whilst $25 \%$ of the plastic wastes are recycled via incineration and another $40 \%$ were disposed to the landfills. The residual 19\% were not duly treated and discharged into the nature. Such techniques of treating the plastic wastes yet are not the best manner to deal with such trouble. Upon 


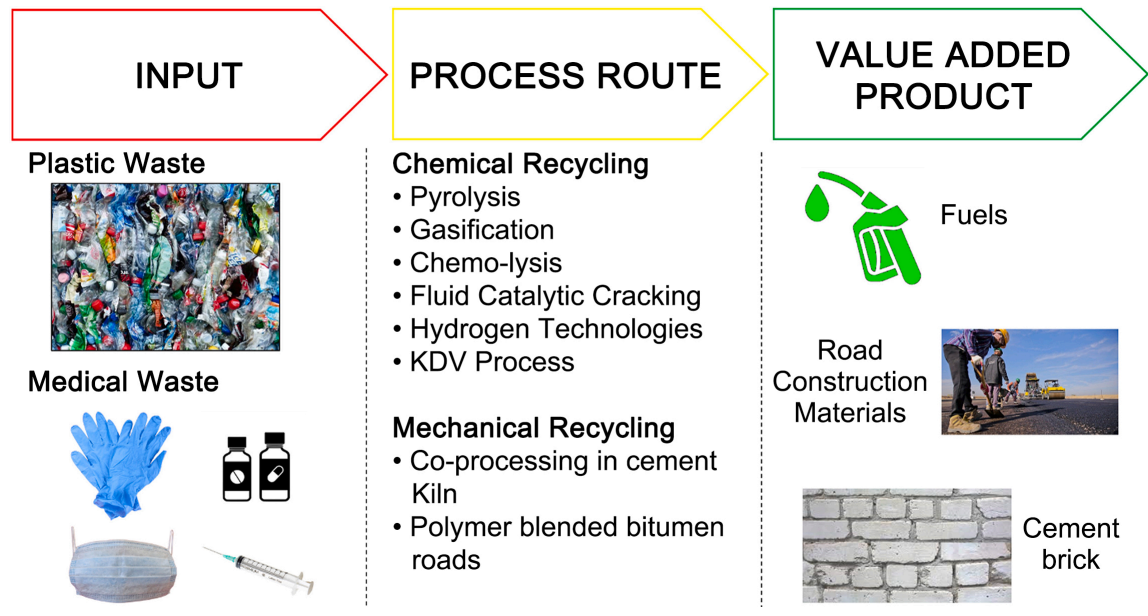

Figure 2. Large estimation of the different process ways in transforming plastic waste to value-added products [1].

the eruption of COVID-19 pandemic, the situation become graver. There are several restrictions like the presence of preservatives in plastics, cross contamination of polymer and incomplete decomposition of polymer when utilizing mechanical methods to recycle the plastic wastes. In order to deal with single-used plastics with minimal impurities, the most efficient procedure remains by recycling. In countries such as India, almost $80 \%$ of PET bottles are recycled. Nonetheless, such technique is not usable to all kinds of plastics, particularly those with weak integral structure. Throughout the COVID-19 catastrophe, the request of recycled plastics appeared to be extremely competitive in the market. Insufficient workers and lockdown in the nations provoke the gathering and treating plastic wastes to become more demanding for the plastic recycling industries. Because of insufficient capital cost, the industries are incapable to employ its full potential and management. Consequently, such circumstance conducts to mismanagement of wastes and disposal to the nature provoking dangerous ecological consequences [1].

In the heart of combating the COVID-19 outbreak, collaboration at a universal level stays demanded to treat the problem of plastic wastes [1]. Concerning plastic contamination, fresh attention was dedicated to substituting plastics with bioplastics. It is well understood that plastic debris of biodegradable plastic would stay in the soil and marine environment for more than three years. For compostable bag, even it will break up in the marine environment during three months, yet the debris stay intact in the soil. Researchers even illustrated that the decomposition of bioplastics into micro- and nano-plastics could threaten marine organisms and conduct to air and soil contamination. Outrageous aggregation of microplastics in the ecosystem constitutes a bigger ecological danger than the initial intact litter. As a result, even if the PPE is formed from bioplastic materials, considering the actual calamity, it would not be a suitable solution since biodegradable plastic solutions alone will not correspond to marine litter reduction. The most fundamental parameter is PPE and all wastes must be conve- 
niently disposed and handled. With a view to diminish the trouble of plastic waste, combined solutions (comprising efficient technology, safe goods, understanding of litter prevention and enforcement of illegal dumping activities by law) will stop huge plastic contamination [1].

With a view to reform the plastic waste management, it is suggested to induce personal behavioral and social developments [1]. Ameliorations could be attained if both these features happen at the same time. Founded on a thorough analysis, numerous short-term and long-term guidelines are listed in Table 2 for policymakers to adopt the requested adjustments to treat the unavoidable elevation in the usage and disposal of single-use plastics after a pandemic [1].

Table 2. Ten guidelines for policymakers to adopt the requested adjustments to deal with the unavoidable augmentation in the usage of single-use plastics after a pandemic [1].

\begin{tabular}{|c|c|}
\hline Guideline & Description \\
\hline Guideline\#1 & $\begin{array}{l}\text { Creating policies that beat psychological and behavioral barriers, comprising } \\
\text { suspicion of reused and recycled product and augmenting public consciousness } \\
\text { of the view of single-use plastic as security rather than a dare. }\end{array}$ \\
\hline Guideline \#2 & $\begin{array}{l}\text { The authority has to furnish specific colored bags to dispose and seal up the } \\
\text { employed PPE for every household. In such condition, it is more appropriate } \\
\text { to separate and treat the biomedical wastes. In public area, a specific color of } \\
\text { bin shall be provided for the PPE items. }\end{array}$ \\
\hline Guideline \#3 & $\begin{array}{l}\text { Promoting investments in the production of good along with hygienic and } \\
\text { recycling purposes. This will spark the innovations and making the current } \\
\text { products fit for different uses. }\end{array}$ \\
\hline Guideline \#4 & $\begin{array}{l}\text { Promoting study in the suggestion of novel techniques to deal with the plastic } \\
\text { packaging [33] [34] [35]. Investing in fresh technology like chemical recycling } \\
\text { appears to be apt to furnish good quality chemicals from plastic wastes. }\end{array}$ \\
\hline Guideline \#5 & $\begin{array}{l}\text { Suggesting bioremediation techniques in wastewater treatment plants } \\
\text { (e.g., microalgae-bacteria consortium [36] [37] [38]) for biodegrading } \\
\text { microplastics [39] [40] [41]. }\end{array}$ \\
\hline Guideline \#6 & $\begin{array}{l}\text { Involving topic related to plastic contamination and the consequences to the } \\
\text { nature in the education. It remains one of the fundamental procedures to } \\
\text { induce awareness of the citizens in the long term. }\end{array}$ \\
\hline Guideline \#7 & $\begin{array}{l}\text { Government must apply rules and regulation like charges for usage of plastic } \\
\text { bags. When the demand lowers, the production will as well diminish. }\end{array}$ \\
\hline Guideline \#8 & $\begin{array}{l}\text { Policy remunerations for productivity in the recycling sector (that frequently } \\
\text { give remunerations for renewable technology) must to be organized differently. } \\
\text { It is crucial to define and provide remunerations to the recycling plants that work } \\
\text { efficiently and cite them through the media to stimulate and motivate others. }\end{array}$ \\
\hline Guideline \#9 & $\begin{array}{l}\text { Concerning the long-term program to ameliorate the performance of recycling the } \\
\text { plastic wastes, it is important to amend policies to diminish multilayer packaging } \\
\text { and promote homogenous plastic packaging materials that are easier to recycle. }\end{array}$ \\
\hline Guideline \#10 & $\begin{array}{l}\text { Companies have a contribution in funding waste management sector field and } \\
\text { foster entrepreneurial avenues in plastic waste management. Thus, the funds } \\
\text { and services allocated by the corporations must be counted as one of the } \\
\text { producer responsibilities. }\end{array}$ \\
\hline
\end{tabular}




\section{Conclusion}

Following the COVID-19 outbreak, the production of plastic wastes has raised greatly [1]. One of the sequels induced throughout the COVID-19 pandemic is the unexpected augmentation of plastic waste, particularly for personal protection and healthcare products. Plastic has a key contribution among of fighting against COVID-19 pandemic since most of the protective equipments are fabricated from plastic materials. The propagation of the pandemic drops a monstrous effect on nature. Tons of plastic wastes have been fabricated throughout the world and most of the wastes are disposed to landfills with lower fractions being recycled. The dependence on plastics has augmented and this will modify our long-term objectives of transitioning towards a circular economy. In a long run, sequels like health-related troubles and ecological contamination will worsen if plastic wastes are not treated correctly. The present system and infrastructure to deal with plastic wastes remain restricted and not efficacious to dominate the fluxes of waste production. Innovations that would stimulate present products and techniques are requested to ameliorate economic and environmental performance. Governmental support with more contingency plans will be required to deal with the plastic wastes problem in the next decades. More efficient and advanced technologies for dealing with the plastic wastes under dangerous catastrophes must be continuously suggested. Every action followed will participate to the importance of such problem since this is a key aim of the community to safe a cleaner and greener nature [1].

\section{Acknowledgements}

The Research Deanship of University of Ha'il, Saudi Arabia, has funded this research through the Project RG-20 113.

\section{Conflicts of Interest}

The authors declare no conflicts of interest regarding the publication of this paper.

\section{References}

[1] Khoo, K.S., Ho, L.Y., Lim, H.R., Leong, H.Y. and Chew, K.W. (2021) Plastic Waste Associated with the COVID-19 Pandemic: Crisis or Opportunity? Journal of Hazardous Materials, 417, Article ID: 126108. https://doi.org/10.1016/j.jhazmat.2021.126108

[2] Gorbalenya, A.E., Koonin, E.V., Donchenko, A.P. and Blinov, V.M. (1989) Coronavirus Genome: Prediction of Putative Functional Domains in the Non-Structural Polyprotein by Comparative Amino Acid Sequence Analysis. Nucleic Acids Research, 17, 4847-4861. https://doi.org/10.1093/nar/17.12.4847

[3] Ghernaout, D. and Elboughdiri, N. (2021) Searching If SARS-CoV-2 Subsists Following the Disinfection of Potable Water. Open Access Library Journal, 8, e7505. https://doi.org/10.4236/oalib.1107505

[4] Zhou, P., Yang, X.L., Wang, X.G., Hu, B., Zhang, L., Zhang, W., Si, H.R., Zhu, Y., 
Li, B., Huang, C.L., Chen, H.D., Chen, J., Luo, Y., Guo, H., Jiang, C.L., Liu, M.Q., Chen, Y., Shen, X.R., Wang, X., Zheng, X.S., Zhao, K., Chen, Q.J., Deng, F., Liu, L.L., Yan, B., Zhan, F.X., Wang, Y.Y., Xiao, G.F. and Shi, Z.L. (2020) A Pneumonia Outbreak Associated with a New Coronavirus of Probable Bat Origin, Nature, 579, 270-273. https://doi.org/10.1038/s41586-020-2012-7

[5] Morawska, L., Tang, J.W., Bahnfleth, W., Bluyssen, P.M., Boerstra, A., Buonanno, G., Cao, J., Dancer, S., Floto, A., Franchimon, F., Haworth, C., Hogeling, J., Isaxon, C., Jimenez, J.L., Kurnitski, J., Li, Y., Loomans, M., Marks, G., Marr, L.C., Mazzarella, L., Melikov, A.K., Miller, S., Milton, D.K., Nazaroff, W., Nielsen, P.V., Noakes, C., Peccia, J., Querol, X., Sekhar, C., Seppänen, O., Tanabe, S.I., Tellier, R., Tham, K.W., Wargocki, P., Wierzbicka, A. and Yao, M. (2020) How Can Airborne Transmission of COVID-19 Indoors Be Minimised? Environment International, 142, Article ID: 105832. https://doi.org/10.1016/j.envint.2020.105832

[6] Ghernaout, D. and Elboughdiri, N. (2021) Exploring What Lies Ahead in the Field of Disinfecting Coronavirus. Open Access Library Journal, 8, e7487. https://doi.org/10.4236/oalib.1107487

[7] Ghernaout, D. and Elboughdiri, N. (2020) Urgent Proposals for Disinfecting Hospital Wastewaters during COVID-19 Pandemic. Open Access Library Journal, 7, e6373. https://doi.org/10.4236/oalib.1106373

[8] Ghernaout, D. and Ghernaout, B. (2020) Controlling COVID-19 Pandemic through Wastewater Monitoring. Open Access Library Journal, 7, e6411. https://doi.org/10.4236/oalib.1106411

[9] Ghernaout, D. and Elboughdiri, N. (2020) Disinfecting Water: Plasma Discharge for Removing Coronaviruses. Open Access Library Journal, 7, e6314. https://doi.org/10.4236/oalib.1106314

[10] Acter, T., Uddin, N., Das, J., Akhter, A., Choudhury, T.R. and Kim, S. (2020) Evolution of Severe Acute Respiratory Syndrome Coronavirus 2 (SARS-CoV-2) as Coronavirus Disease 2019 (COVID-19) Pandemic: A Global Health Emergency. Science of the Total Environment, 730, Article ID: 138996.

https://doi.org/10.1016/j.scitotenv.2020.138996

[11] Chen, W.Q., Ciacci, L., Sun, N.N. and Yoshioka, T. (2020) Sustainable Cycles and Management of Plastics: A Brief Review of RCR Publications in 2019 and Early 2020. Resources, Conservation \& Recycling, 159, Article ID: 104822. https://doi.org/10.1016/j.resconrec.2020.104822

[12] Saadat, S., Rawtani, D. and Hussain, C.M. (2020) Environmental Perspective of COVID-19. Science of the Total Environment, 728, Article ID: 138870. https://doi.org/10.1016/j.scitotenv.2020.138870

[13] Kalina, M. and Tilley, E. (2020) “This Is Our Next Problem”: Cleaning Up from the COVID-19 Response. Waste Management, 108, 202-205.

https://doi.org/10.1016/j.wasman.2020.05.006

[14] Alfarisi, S. and Sutopo, W. (2019) Simulation of Green Operations Supply Chain in Waste of Plastic. IOP Conference Series: Materials Science and Engineering, 495, Article ID: 012080. https://doi.org/10.1088/1757-899X/495/1/012080

[15] Ragaert, K., Delva, L. and van Geem, K. (2017) Mechanical and Chemical Recycling of Solid Plastic Waste. Waste Management, 69, 24-58.

https://doi.org/10.1016/j.wasman.2017.07.044

[16] Miandad, R., Barakat, M.A., Rehan, M., Aburiazaiza, A.S., Ismail, I.M.I. and Nizami, A.S. (2017) Plastic Waste to Liquid Oil through Catalytic Pyrolysis Using Natural and Synthetic Zeolite Catalysts. Waste Management, 69, 66-78. 
https://doi.org/10.1016/j.wasman.2017.08.032

[17] Owusu, P.A., Banadda, N., Zziwa, A., Seay, J. and Kiggundu, N. (2018) Reverse Engineering of Plastic Waste into Useful Fuel Products. Journal of Analytical and Applied Pyrolysis, 130, 285-293. https://doi.org/10.1016/j.jaap.2017.12.020

[18] Xu, F., Wang, B., Yang, D., Hao, J., Qiao, Y. and Tian, Y. (2018) Thermal Degradation of Typical Plastics under High Heating Rate Conditions by TG-FTIR: Pyrolysis Behaviors and Kinetic Analysis. Energy Conversion and Management, 171, 11061115. https://doi.org/10.1016/j.enconman.2018.06.047

[19] Ding, K., Liu, S., Huang, Y., Liu, S., Zhou, N., Peng, P., Wang, Y., Chen, P. and Ruan, R. (2019) Catalytic Microwave-Assisted Pyrolysis of Plastic Waste over NiO and HY for Gasoline-Range Hydrocarbons Production. Energy Conversion and Management, 196, 1316-1325. https://doi.org/10.1016/j.enconman.2019.07.001

[20] Wong, S.L., Ngadi, N., Abdullah, T.A.T. and Inuwa, I.M. (2015) Current State and Future Prospects of Plastic Waste as Source of Fuel: A Review, Renewable and Sustainable Energy Reviews, 50, 1167-1180. https://doi.org/10.1016/j.rser.2015.04.063

[21] Miandad, R., Barakat, M.A., Aburiazaiza, A.S., Rehan, M., Ismail, I.M.I. and Nizami, A.S. (2016) Effect of Plastic Waste Types on Pyrolysis Liquid Oil. International Biodeterioration \& Biodegradation, 119, 239-252.

https://doi.org/10.1016/j.ibiod.2016.09.017

[22] Mahari, W.A.W., Chong, C.T., Cheng, C.K., Lee, C.L., Hendrata, K., Yek, P.N.Y., Ma, N.L. and Lam, S.S. (2018) Production of Value-Added Liquid Fuel via Microwave Co-Pyrolysis of Used Frying Oil and Plastic Waste. Energy, 162, 309-317. https://doi.org/10.1016/j.energy.2018.08.002

[23] Ghernaout, D. and Elboughdiri, N. (2020) UV-C/ $\mathrm{H}_{2} \mathrm{O}_{2}$ and Sunlight $/ \mathrm{H}_{2} \mathrm{O}_{2}$ in the Core of the Best Available Technologies for Dealing with Present Dares in Domestic Wastewater Reuse. Open Access Library Journal, 7, e6161. https://doi.org/10.4236/oalib.1106161

[24] Santaweesuk, C. and Janyalertadun, A. (2017) The Production of Fuel Oil by Conventional Slow Pyrolysis Using Plastic Waste from a Municipal Landfill. International Journal of Environmental Studies, 8, 168-173.

https://doi.org/10.18178/ijesd.2017.8.3.941

[25] Ghernaout, D. (2019) Greening Cold Fusion as an Energy Source for Water Treatment Distillation-A Perspective. American Journal of Quantum Chemistry and Molecular Spectroscopy, 3, 1-5.

[26] Arulrajah, A., Yaghoubi, E., Wong, Y.C. and Horpibulsuk, S. (2017) Recycled Plastic Granules and Demolition Wastes as Construction Materials: Resilient Moduli and Strength Characteristics. Construction and Building Materials, 147, 639-647. https://doi.org/10.1016/j.conbuildmat.2017.04.178

[27] Jassim, A.K. (2017) Recycling of Polyethylene Waste to Produce Plastic Cement. Procedia Manufacturing, 8, 635-642. https://doi.org/10.1016/j.promfg.2017.02.081

[28] Bhogayata, A.C. and Arora, N.K. (2019) Utilization of Metalized Plastic Waste of Food Packaging Articles in Geopolymer Concrete. Journal of Material Cycles and Waste Management, 21, 1014-1026. https://doi.org/10.1007/s10163-019-00859-9

[29] Thorneycroft, J., Orr, J., Savoikar, P. and Ball, R.J. (2018) Performance of Structural Concrete with Recycled Plastic Waste as a Partial Replacement for Sand. Construction and Building Materials, 161, 63-69. https://doi.org/10.1016/j.conbuildmat.2017.11.127

[30] Pandey, S., Karakoti, M., Dhali, S., Karki, N., SanthiBhushan, B., Tewari, C., Rana, 
S., Srivastava, A., Melkani, A.B. and Sahoo, N.G. (2019) Bulk Synthesis of Graphene Nanosheets from Plastic Waste: An Invincible Method of Solid Waste Management for Better Tomorrow. Waste Management, 88, 48-55.

https://doi.org/10.1016/j.wasman.2019.03.023

[31] Veksha, A., Giannis, A. and Chang, V.W.C. (2017) Conversion of Non-Condensable Pyrolysis Gases from Plastics into Carbon Nanomaterials: Effects of Feedstock and Temperature. Journal of Analytical and Applied Pyrolysis, 124, 16-24. https://doi.org/10.1016/j.jaap.2017.03.005

[32] El-Sayed, E.-S.M. and Yuan, D. (2020) Waste to MOFs: Sustainable Linker, Metal, and Solvent Sources for Value-Added MOF Synthesis and Applications. Green Chemistry, 22, 4082-4104. https://doi.org/10.1039/D0GC00353K

[33] Ghernaout, D. (2017) Environmental Principles in the Holy Koran and the Sayings of the Prophet Muhammad. American Journal of Environmental Protection, 6, 75-79. https://doi.org/10.11648/j.ajep.20170603.13

[34] Ghernaout, D., Ghernaout, B. and Naceur, M.W. (2011) Embodying the Chemical Water Treatment in the Green Chemistry-A Review. Desalination, 271, 1-10. https://doi.org/10.1016/j.desal.2011.01.032

[35] Ghernaout, D. (2013) The Best Available Technology of Water/Wastewater Treatment and Seawater Desalination: Simulation of the Open Sky Seawater Distillation. Green and Sustainable Chemistry, 3, 68-88. https://doi.org/10.4236/gsc.2013.32012

[36] Ghernaout, D. and Elboughdiri, N. (2020) Eliminating Cyanobacteria and Controlling Algal Organic Matter-Short Notes. Open Access Library Journal, 7, e6252. https://doi.org/10.4236/oalib.1106252

[37] Ghernaout, D. and Ghernaout, B. (2012) On the Concept of the Future Drinking Water Treatment Plant: Algae Harvesting from the Algal Biomass for Biodiesel Production-A Review. Desalination and Water Treatment, 49, 1-18. https://doi.org/10.1080/19443994.2012.708191

[38] Al Arni, S., Amous, J. and Ghernaout, D. (2019) On the Perspective of Applying of a New Method for Wastewater Treatment Technology: Modification of the Third Traditional Stage with Two Units, One by Cultivating Microalgae and Another by Solar Vaporization. International Journal of Environmental Sciences \& Natural Resources, 16, Article ID: 555934. https://doi.org/10.19080/IJESNR.2019.16.555934

[39] Ghernaout, D. and Elboughdiri, N. (2020) Domestic Wastewater Treatment: Difficulties and Reasons, and Prospective Solutions-China as an Example. Open Access Library Journal, 7, e6141.

[40] Ghernaout, D. and Elboughdiri, N. (2020) Advanced Oxidation Processes for Wastewater Treatment: Facts and Future Trends. Open Access Library Journal, 7, e6139.

[41] Ghernaout, D. and Elboughdiri, N. (2020) On the Treatment Trains for Municipal Wastewater Reuse for Irrigation. Open Access Library Journal, 7, e6088. 